\title{
Discovery and antibacterial activity of glabramycin A-C from Neosartorya glabra by an antisense strategy
}

\author{
Hiranthi Jayasuriya ${ }^{1}$, Deborah Zink ${ }^{1}$, Angela Basilio ${ }^{2}$, Francisca Vicente ${ }^{2}$, Javier Collado ${ }^{2}$, Gerald Bills ${ }^{2}$, \\ Mary Lee Goldman ${ }^{1}$, Mary Motyl ${ }^{1}$, Joann Huber ${ }^{1}$, Gabe Dezeny ${ }^{1}$, Kevin Byrne ${ }^{1}$ and Sheo B Singh ${ }^{1}$
}

Treatment of drug-resistant bacteria is a significant unmet medical need. This challenge can be met only by the discovery and development of new antibiotics. Antisense technology is one of the newest discovery tools that provides enhanced sensitivity for detection of antibacterials, and has led to the discovery of a number of interesting new antibacterial natural products. Continued utilization of this technology led to the discovery of three new bicyclic lactones, glabramycins A-C, from a Neosartorya glabra strain. Glabramycin C showed strong antibiotic activity against Streptococcus pneumoniae (MIC $2 \mu \mathrm{g} \mathrm{ml}^{-1}$ ) and modest antibiotic activity against Staphylococcus aureus (MIC $16 \mu \mathrm{g} \mathrm{ml}^{-1}$ ). The isolation, structure, relative configuration and antibacterial activity, and plausible biogenesis of these compounds have been discussed.

The Journal of Antibiotics (2009) 62, 265-269; doi:10.1038/ja.2009.26; published online 3 April 2009

Keywords: antisense; rpsD; Neosartorya; glabra; glabramycin; antibacterial; Staphylococcus aureus

\section{INTRODUCTION}

The discovery and development of clinically useful antibiotic classes, such as, the aminoglycosides, macrolides and tetracyclines, have clearly shown that bacterial protein synthesis is a viable target for antibacterial drug discovery. ${ }^{1,2}$ The bacterial ribosome responsible for protein synthesis consists of a small $30 \mathrm{~S}$ and a large $50 \mathrm{~S}$ subunit. The ribosomal subunit (aka S4), referred to as RpsD, is a component of the 30 S subunit. ${ }^{3-5}$ The $\mathrm{RpsD}$ protein is encoded by the $r p s \mathrm{D}$ gene, which is essential and resides in an operon containing only one other gene, SAV1718, which is a nonessential gene. ${ }^{6,7}$ Therefore, this gene was selected as a drug-target for the discovery of antibacterial agents.

For antibiotic discovery targeting the $r p s \mathrm{D}$ gene, we constructed a Staphylococcus aureus S1-782B strain expressing antisense RNA under xylose control, leading to hypersensitivity against RpsD inhibitors. To implement this approach for drug discovery, we designed a two-plate assay in which one plate was seeded with an $r p s \mathrm{D}$ antisense $S$. aureus strain and the other with an S. aureus EP 167 (control) strain. A similar general methodology led to the discovery of platensimycin and platencin. ${ }^{8-13}$ The screening of over 138000 microbial extracts against $r p s \mathrm{D}$ two-plate antisense whole-cell assay led to the isolation of a series of interesting new compounds exemplified by lucensimycins, ${ }^{14-16}$ coniothyrione, ${ }^{17}$ pleosporone, ${ }^{18}$ phaeosphenone, ${ }^{19}$ and okilactomycin. ${ }^{20}$ Continued screening and follow-up of one of the active extracts produced by Neosartorya glabra led to the isolation of three macrolactones namely, glabramycin $\mathrm{A}-\mathrm{C}$ (1-3, Figure 1). The isolation, structure elucidation, relative configuration and antibacterial activity of the glabramycins (1-3) are described.

\section{RESULTS AND DISCUSSION}

The producing organism was isolated from a soil sample collected from Candamia, Spain. The strain was identified as Neosartorya glabra by sequencing the large subunit of DNA of the D1D2 region and by tracing the phylogenetic relationships. The strain was grown in a submerged fermentation for 14 days and compounds were extracted with an equal volume of acetone. The extract was chromatographed on Amberchrome, a capture resin, followed by reversed-phase $\mathrm{C}_{8}$ HPLC to give $1\left(7 \mathrm{mg}, 7 \mathrm{mgl}^{-1}\right), 2\left(1.9 \mathrm{mg}, 1.9 \mathrm{mgl}^{-1}\right)$ and 3 ( $1 \mathrm{mg}, 1 \mathrm{mgl}^{-1}$, each as yellow gums.

Glabramycin A (1), the most abundant of the three compounds, showed a molecular formula $\mathrm{C}_{22} \mathrm{H}_{24} \mathrm{O}_{6}$ as deduced from the HRESIFTMS data. The ${ }^{13} \mathrm{C}$ NMR spectrum and distortionless enhancement by polarization transfer (DEPT) analysis of $\mathbf{1}$ showed signals for one methyl, four methylenes, ten methines and seven quaternary carbons (Table 1 ). The ${ }^{1} \mathrm{H}$ NMR spectrum showed signals for four olefinic methine doublet of doublets with $J=15$ and $11 \mathrm{~Hz}$, and two methine doublets with $J=15 \mathrm{~Hz}$. The COSY correlations of these six olefinic methines indicated the presence of an E-triene in which each end terminated with a quaternary carbon. The methine $\left(\delta_{\mathrm{H}}\right.$ 5.90) at one end of the triene chain showed heteronuclear multiple bond correlations (HMBCs) to a carboxyl carbon at $\delta_{\mathrm{C}}$ 170.3 , and a carboxylic group was thus placed at one end of the triene. The terminal methine $\left(\delta_{\mathrm{H}} 6.00\right)$ at the other end of the triene chain showed HMBC correlations to two quaternary olefinic carbons resonating at $\delta_{\mathrm{C}} 167.4$ and $\delta_{\mathrm{C}} 108.6$, allowing for further extension of the triene chain. 


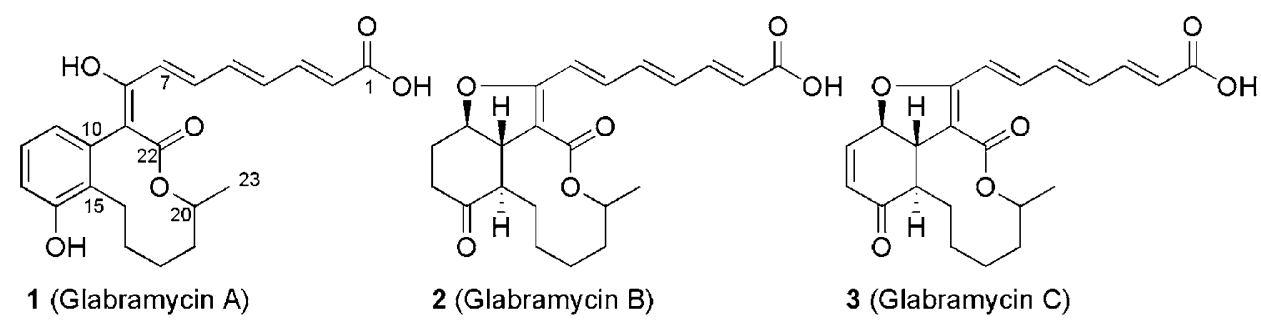

Figure 1 Structures and relative configurations of glabramycins A-C (1-3).

Table $1{ }^{1} \mathrm{H}(600 \mathrm{MHz})$ and ${ }^{13} \mathrm{C}(125 \mathrm{MHz})-N M R$ assignments of glabramycin A (1), B (2) and C (3)

\begin{tabular}{|c|c|c|c|c|c|c|}
\hline & 1 & $\begin{array}{l}1 \\
C D_{3} O D\end{array}$ & 2 & $\begin{array}{l}2 \\
C D_{3} O D\end{array}$ & 3 & $\begin{array}{l}3 \\
\mathrm{CDCl}_{3}\end{array}$ \\
\hline Position & $\delta_{c}$ & $\delta_{\mathrm{H}}$, mult, $J$ in $\mathrm{Hz}$ & $\delta_{c}$ & $\delta_{\mathrm{H}}$, mult, $J$ in $\mathrm{Hz}$ & $\delta_{c}$ & $\delta_{\mathrm{H}}$, mult, $J$ in $\mathrm{Hz}$ \\
\hline 1 & 170.3 & & 170.1 & & 170.8 & \\
\hline 2 & 124.4 & $5.90, d, 15$ & 124.5 & $6.00, d, 15$ & 122.2 & $5.90, d, 15$ \\
\hline 3 & 145.6 & 7.30, dd, 15, 11 & 145.2 & 7.30, dd, 15, 11 & 145.5 & $7.40, \mathrm{dd}, 15,11$ \\
\hline 6 & 136.9 & $7.10, \mathrm{dd}, 15,11$ & 137.3 & $7.00, \mathrm{dd}, 15,11$ & 135.9 & $6.97, \mathrm{dd}, 15,11$ \\
\hline 7 & 129.1 & $6.0, d, 15$ & 123.3 & $7.20, d, 15$ & 122.9 & $7.32, d, 15$ \\
\hline 8 & 167.4 & & 164.5 & & 163.1 & \\
\hline 9 & 108.6 & & 110.9 & & 112.0 & \\
\hline 14 & 157.4 & & 213.3 & & 198.7 & \\
\hline 15 & 131.8 & & 50.6 & $2.60, \mathrm{~m}$ & 48.3 & $2.46, \mathrm{~m}$ \\
\hline \multirow[t]{2}{*}{16} & 27.3 & $\begin{array}{l}2.07, m \\
2.70, m\end{array}$ & 23.7 & $\begin{array}{l}\text { 1.46, m, } \\
1.62, \mathrm{~m}\end{array}$ & 22.9 & $\begin{array}{l}2.05, \mathrm{~m} \\
1.40, \mathrm{~m}\end{array}$ \\
\hline & & $1.94, \mathrm{~m}$ & & $1.80, \mathrm{~m}$ & & $1.53, \mathrm{~m}$ \\
\hline \multirow[t]{2}{*}{17} & 29.5 & $1.87, \mathrm{~m}$ & 25.2 & $1.30, \mathrm{~m}$ & 23.6 & $1.89, \mathrm{~m}$ \\
\hline & & $1.34, \mathrm{~m}$ & & $1.78, \mathrm{~m}$ & & $1.65, \mathrm{~m}$ \\
\hline \multirow[t]{2}{*}{18} & 22.6 & $1.53, \mathrm{~m}$ & 24.9 & $1.88, \mathrm{~m}$ & 32.4 & $1.76, \mathrm{~m}$ \\
\hline & & $1.49, \mathrm{~m}$ & & $1.56, \mathrm{~m}$ & & $1.38, \mathrm{~m}$ \\
\hline 19 & 33.9 & $1.83, \mathrm{~m}$ & 32.9 & $1.83, \mathrm{~m}$ & 24.8 & $1.77, \mathrm{~m}$ \\
\hline
\end{tabular}

Three of the remaining olefinic methines coupled with each other, with $J=7.5 \mathrm{~Hz}$ indicating the presence of a 1,2,3-tri-substituted phenyl group. The only non-olefinic methine proton resonating at $\delta_{\mathrm{H}}$ 5.30 showed heteronuclear multiple quantum coherence (HMQC) correlation to an oxygenated carbon resonating at $\delta_{\mathrm{C}} 73.5$. The methyl group resonating at $\delta_{\mathrm{H}} 1.10$ showed $\mathrm{HMBC}$ correlations to the methine carbon $\mathrm{C}-20\left(\delta_{\mathrm{C}} 73.5\right)$ and to the methylene at C-19 $\left(\delta_{\mathrm{C}}\right.$ 33.9). This observation allowed for the placement of the methyl group on the oxygenated carbon C-20. The COSY correlations from the methyl protons, $\mathrm{H}_{3}-23$ at $\delta_{\mathrm{H}} 1.10$ to the methylene $\mathrm{H}_{2}-16$ at $\delta_{\mathrm{H}} 2.07$ and $\delta_{\mathrm{H}} 2.7$, established the C16-C20-C23 spin system. The HMBC correlations of the terminal methylene protons of the alkyl chain at $\delta_{\mathrm{H}}$ 2.70 and $\delta_{\mathrm{H}} 2.07$ to carbons $\delta_{\mathrm{C}} 131.8$ (C-15), 125.3 (C-10) and 157.4
(C-14) established its connection to the phenyl group. The HMBC correlation of the methine proton $\left(\delta_{\mathrm{H}} 5.30\right)$ to an ester carbonyl at $\delta_{\mathrm{C}}$ 164.7 (C-22) allowed for the linkage of this carbonyl and the methine in the form of a lactone ring. Finally, the ester carbonyl C-22 was connected to the olefinic carbon C-9 $\left(\delta_{\mathrm{C}} 108.6\right)$ to form the macrocyclic lactone, to satisfy the degrees of unsaturation and the molecular formula. This assignment was supported by the ${ }^{13} \mathrm{C}$ chemical shifts of C-8, C-9 and C-22. The substitution around the phenyl ring was confirmed by HMBC correlations of the aromatic protons and supported by HMBC correlations of the benzylic methylene protons (Figure 2).

The structures for glabramycins, B (2) and C (3), were determined by comparison of ${ }^{13} \mathrm{C}$ and ${ }^{1} \mathrm{H}$ NMR spectral data with $\mathbf{1}$ (Table 1 ). 
Glabramycin B (2) exhibited a molecular formula, $\mathrm{C}_{22} \mathrm{H}_{26} \mathrm{O}_{6}$. The ${ }^{1} \mathrm{H}$ NMR spectrum of $\mathbf{2}$ showed only six olefinic protons of trienoic acid moiety, indicating the presence of a saturated six-membered ring system. The COSY spectrum showed an extended spin system comprising $\mathrm{C} 20(\mathrm{C} 23)-\mathrm{C} 15-\mathrm{C} 10-\mathrm{C} 14$. The HMBC correlations of $\mathrm{H}-10\left(\delta_{\mathrm{H}}\right.$ 3.46), $\mathrm{H}_{2}-12\left(\delta_{\mathrm{H}} 2.20,2.40\right)$ and $\mathrm{H}_{2}-16\left(\delta_{\mathrm{H}} 1.46,1.62\right)$ to the downfield carbonyl C-14 $\left(\delta_{\mathrm{C}} 213.3\right)$ allowed the placement of a carbonyl group at $\mathrm{C}-14$ in the cyclohexanone ring. The ether bridge between $\mathrm{C} 8$ and $\mathrm{C} 11$ made the dihydrofuran ring that satisfied the molecular formula. The relative configurations at C-10, C-11 and $\mathrm{C}-15$ were established from the magnitude of the scalar couplings. $\mathrm{H}-10$ resonated as a triplet with $J=9.6 \mathrm{~Hz}$ because of axial-axial couplings both from $\mathrm{H}-11$ and $\mathrm{H}-15$, thus establishing an anti relationship between these three protons and a trans-ring fusion.

Glabramycin C (3) showed a molecular formula that was isomeric to that of 1 . Comparison of the ${ }^{1} \mathrm{H}$ and ${ }^{13} \mathrm{C}$ NMR spectra of 3 with those of compound 2 indicated the presence of a pair of olefinic protons, $\delta_{\mathrm{H}} 6.23(\mathrm{~d}, J=10.5 \mathrm{~Hz})$ and $6.87(\mathrm{dd}, J=10.5,4.5 \mathrm{~Hz})$, which were assigned to $\mathrm{H}-13$ and $\mathrm{H}-12$ by COSY correlations and confirmed by their HMBC correlations to an upfield shifted C-14 carbonyl $\left(\delta_{\mathrm{C}}\right.$ 198.7), thus assigning structure 3 for glabramycin C (Table 1).

On the basis of these data, structures 1, 2 and 3, with relative configurations, were assigned for glabramycins $\mathrm{A}, \mathrm{B}$ and $\mathrm{C}$, respectively. Biogenetically, these compounds are likely to originate from a

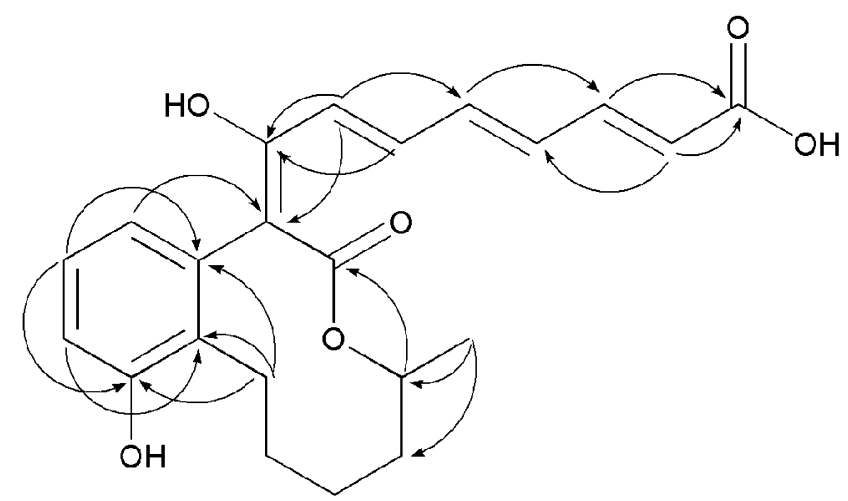

Figure 2 Heteronuclear multiple bond correlations (HMBC) of glabramycin A (1). polyketide pathway by condensation of 11 acetate units to a undecaketide, which likely undergoes cyclization, reduction and dehydration to produce compound $\mathbf{1}$, which then produces compounds 3 and 2 .

\section{Biological activities}

All three glabramycins were tested in the S. aureus antisense $r p s D$ sensitized two-plate differential sensitivity assay. Glabramycin $\mathrm{C}$ showed the most potent activity in this assay and showed a minimum detection concentration (MDC) of $62 \mu \mathrm{g} \mathrm{ml}^{-1}$. At this concentration, a more than $5 \mathrm{~mm}$ zone differential was observed with a $10.78 \mathrm{~mm}$ zone of inhibition on the antisense plate vs a $5.63 \mathrm{~mm}$ zone of inhibition on the control plate. The size of the zone of clearance was dose dependent, and at $500 \mu \mathrm{g} \mathrm{ml}^{-1}$, it produced a zone of clearance of 16.89 and $6.8 \mathrm{~mm}$ on the antisense and the control plate, respectively. The other two compounds were less active. Glabramycin A was approximately four-fold less active and showed intermediate activity with MDC of $250 \mu \mathrm{g} \mathrm{ml}^{-1}$, producing zone sizes of 11.24 and $6.25 \mathrm{~mm}$ on the antisense and the control plate, respectively. The MDC of glabramycin $\mathrm{B}$ was greater than $500 \mu \mathrm{g} \mathrm{ml}^{-1}$. Glabramycin $\mathrm{C}$ showed better activity against a panel of bacteria used in this assay. It inhibited S. aureus growth with MIC values of $16 \mu \mathrm{g} \mathrm{ml}^{-1}$ (Table 2). Glabramycin C exhibited a similar activity against Bacillus subtilis, but was less active against Enterococcus faecalis ( $\mathrm{MIC}>32 \mu \mathrm{g} \mathrm{m}^{-1}$ ). The best activity was against Streptococcus pneumoniae regardless of the medium used, and inhibited the growth with an MIC value of $2 \mu \mathrm{g} \mathrm{ml}^{-1}$. Glabramycins A and B were significantly less active, see Table 2. None of these compounds inhibited growth of Gram-negative bacteria or fungi Candida albicans. Mechanistically, glabramycin A, the most abundant of the three, showed 2-3-fold preferential inhibition of RNA synthesis ( $\mathrm{IC}_{50}$ $10 \mu \mathrm{g} \mathrm{ml}^{-1}$ ) compared with DNA and protein synthesis in a macromolecular synthesis assay (Figure 3 ). Inhibition of RNA synthesis, $\mathrm{IC}_{50}$ $\left(10 \mu \mathrm{g} \mathrm{ml}^{-1}\right)$, of $S$. aureus is 10 times more potent than the MIC value $\left(100 \mu \mathrm{g} \mathrm{ml}^{-1}\right)$ against the same $S$. aureus strain. Why the compounds discovered in this assay preferentially inhibit RNA synthesis rather than the expected protein synthesis is not clear and requires further investigation.

No compounds have earlier been reported from N. glabra strain, but a large number of biologically active compounds have been reported from genera Neosartorya, for example, the angiogenesis inhibitor, azaspirene. ${ }^{21}$ It seems that the most chemically studied

Table 2 Antibacterial activities (MIC, $\left.\mu \mathrm{g} \mathrm{ml}^{-1}\right)^{\mathrm{a}}$ of glabramycins A-C (1-3)

\begin{tabular}{|c|c|c|c|c|c|}
\hline Strains $^{\mathrm{b}}$ & Phenotype & Strain \# & $1^{\mathrm{c}}$ & $2^{c}$ & $3^{c}$ \\
\hline S. aureus & meth $^{S}$ & ATCC 29213 & $>64$ & $>64$ & 16 \\
\hline S. aureus & meth $^{S}$ & MB2865 & $>64(64)$ & $>64$ & $16(8)$ \\
\hline S. aureus (+50\% human serum) & meth ${ }^{S}$ & MB2865 & $>64$ & $>64$ & $>32$ \\
\hline S. pneumoniae ${ }^{\mathrm{d}}$ & pen $^{\mathrm{S}}$, quins, $\mathrm{mac}^{\mathrm{s}}$ & CL2883 & $>64$ & 4 & 2 \\
\hline S. pneumoniae $\mathrm{e}^{\mathrm{e}}$ & pen $^{\mathrm{S}}$, quins ${ }^{\mathrm{S}}$, mac $\mathrm{s}$ & CL2883 & 32 & 64 & 2 \\
\hline E. faecalis & $\operatorname{van}^{\mathrm{S}}, \mathrm{mac}^{\mathrm{R}}$ & CL8516 & $>64$ & $>64$ & $>32(32)$ \\
\hline B. subtilis & Wt & MB964 & $>64$ & $>64$ & 16 \\
\hline H. influenzae & $\mathrm{Amp}^{\mathrm{S}}$, quin ${ }^{\mathrm{S}}, \mathrm{mac}^{\mathrm{S}}$ & MB4572 & $>64$ & $>64$ & $>64$ \\
\hline E. coli & Wt & MB2884 & $>64$ & $>64$ & $>32$ \\
\hline E. coli envA/tolC & Wt & MB2884 & 64 & $>64$ & $>32$ \\
\hline C. albicans & Wt & MY1055 & $>64$ & $>64$ & $>32$ \\
\hline
\end{tabular}

Abbreviations: CAMHB, cation adjusted Mueller-Hinton broth; MIC, minimum inhibitory concentration; MIC 80 , minimum inhibitory concentration that inhibits $80 \%$ growth. aMIC determined using NLSI protocols.

bAll strains were tested in CAMHB medium, unless mentioned otherwise, under National Committee for Clinical laboratory Standards (NCCLS) guidelines.

CThe data in parentheses are MIC80 values.

${ }^{d} \mathrm{CAMHB}+2.5 \%$ lysed horse blood medium.

eIsosensitet medium. 


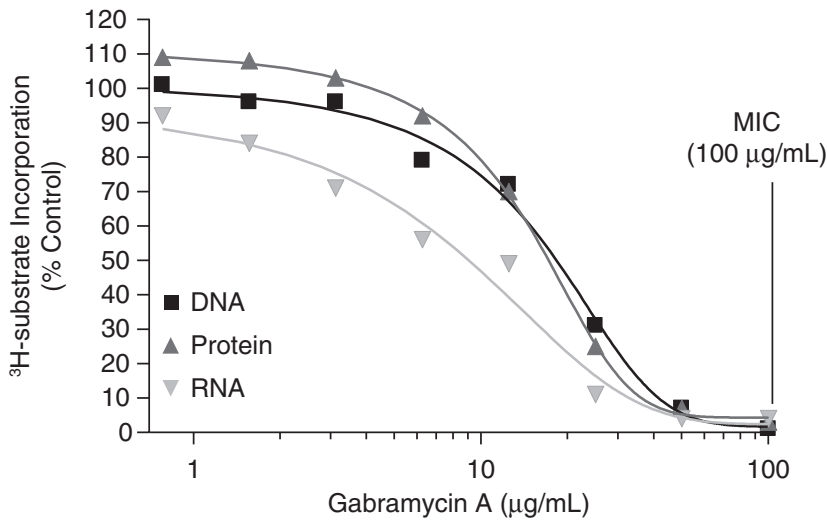

Figure 3 Macromolecular synthesis inhibition by glabramycin A (1) in S. aureus. No significant preference to inhibition of DNA, RNA and protein synthesis was observed.

species is Neosartorya fischeri, which is known to produce substance $\mathrm{P}$ inhibitors namely the fiscalins, ${ }^{22}$ the toxin fischerin ${ }^{23}$ and the tremorgenic mycotoxins, fumitremorgins, ${ }^{23}$ neosartorrin, ${ }^{24}$ and terreins. ${ }^{25}$

In conclusion, it is evident that the antisense screening approach provides higher sensitivity and allows the discovery of antibiotics with weaker activity, exemplified by the discovery of the three new compounds, glabramycins A-C. One of the three compounds showed moderate antibacterial activity without being a general toxin and can be exploited further. Screening using an antisense sensitized $r p s D$ strains of $S$. aureus led to the isolation of a number of antibacterial agents that do not preferentially inhibit protein synthesis but often RNA synthesis. Understanding of this phenomenon requires further study. ${ }^{14,15,17-19}$ Although lack of selectivity for protein synthesis inhibition by compounds discovered by $r p s D$-sensitized antisense screening is perplexing, it cannot be merely explained as a generalized technology artifact, because a similar screening approach using a fabFsensitized strain led to the discoveries of platensimycin and platencin, highly selective fatty-acid synthesis inhibitors. ${ }^{10,11}$

\section{EXPERIMENTAL SECTION}

For general experimental procedure, see, for example, Zhang et al. ${ }^{26}$

\section{Producing organism}

The N. glabra (MF7030, F-155,700) strains were isolated from hot waterpasteurized soil collected from Candamia, near Valdefresno province of León, Spain. The ascomata, ascospores and conidial states were observed on malt yeast extract agar and were readily recognized as a species of Neosartorya (Ascomycota, Eurotiales).

The DNA of strain F-155,700 was extracted and used as a template for polymerase chain reaction (PCR) reactions. The D1D2 region of the large subunit of ribosomal DNA (LSU rDNA) was amplified and sequenced to aid in identification and to infer phylogenetic relationships of the strains to other fungi. The sequences were used to query GenBank for similar ribosomal sequences. The best matches with the large subunit (LSU) region and the percentage similarities were: N. glabra (U28456) 99\%.

Inoculum was prepared by inoculating agar plugs into a $250 \mathrm{ml}$ Erlenmeyer flask containing $60 \mathrm{ml}$ seed medium of the following composition: $\mathrm{gl}^{-1}$ in distilled water (corn steep powder, 2.5; tomato paste, 40.0; oat flour; 10.0; glucose, 10.0; $\mathrm{FeSO}_{4} \cdot 7 \mathrm{H}_{2} \mathrm{O}, 0.01 ; \mathrm{MnSO}_{4} \cdot 4 \mathrm{H}_{2} \mathrm{O}, 0.01 ; \mathrm{CuCl}_{2} \cdot 2 \mathrm{H}_{2} \mathrm{O}, 0.0025$; $\mathrm{CaCl}_{2} \cdot 2 \mathrm{H}_{2} \mathrm{O}, \quad 0.001 ; \quad \mathrm{H}_{3} \mathrm{BO}_{3}, \quad 0.00056 ; \quad\left(\mathrm{NH}_{4}\right)_{6} \mathrm{MoO}_{24} \cdot 4 \mathrm{H}_{2} \mathrm{O}, \quad 0.00019$; $\left.\mathrm{ZnSO}_{4} \cdot 7 \mathrm{H}_{2} \mathrm{O}, 0.01\right)$. The $\mathrm{pH}$ was adjusted to 6.8 before autoclaving. The seed culture was incubated for 5 days at $22^{\circ} \mathrm{C}$ on a gyratory shaker $\left(220 \mathrm{rev} \mathrm{min}{ }^{-1}\right)$ before the inoculation of the production medium. The production medium, designated asWS80, consisted of $\mathrm{g} / \mathrm{l}$ in distilled water (whole wheat flour (Pillsbury), 50; xylose, 40; and fructose, 40). The $100 \mathrm{ml}$ medium aliquots was dispensed in $500 \mathrm{ml}$ Erlenmeyer flasks, inoculated with $1 \%$ volume of the seed culture, and were agitated for 14 days at $22^{\circ} \mathrm{C}$.

\section{Extraction and isolation of glabramycins}

One 1 fermentation broth (10 flasks) was extracted with one 1 acetone by shaking for $1 \mathrm{~h}$ after the harvest. The acetone extract (2l) was evaporated under reduced pressure to less than one liter and further diluted with $500 \mathrm{ml}$ water and loaded onto a $50 \mathrm{cc}$ Amberchrome CG161 m (Rohm \& Haas, Reading, PA, USA) column. The column was eluted with a $100 \mathrm{~min} 10-100 \%$ aqueous methanol-gradient. The activity was detected in a late eluting band. The active fraction $(600 \mathrm{mg})$ was further purified by repeated reversed-phase HPLC $\left(50 \%\right.$ aqueous $\mathrm{CH}_{3} \mathrm{CN}+0.1 \%$ TFA on a Zorbax SB $\mathrm{C}_{8}, 24 \times 250 \mathrm{~mm}$, Agilent Technologies, Santa Clara, CA, USA). The identical fractions were pooled from 10 runs and lyophilized to afford glabramycin A $(7 \mathrm{mg}, 7 \mathrm{mg} / \mathrm{l})$, glabramycin B $(1.9 \mathrm{mg}, 1.9 \mathrm{mg} / \mathrm{l})$ and glabramycin C $(1 \mathrm{mg}, 1 \mathrm{mg} / \mathrm{l})$ as yellow gums.

Glabramycin A (1): $[\alpha]^{23}{ }_{\mathrm{D}}+7.7\left(c 0.44, \mathrm{CH}_{3} \mathrm{OH}\right), \mathrm{UV}\left(\mathrm{CH}_{3} \mathrm{OH}\right) \lambda_{\max } 278$ (log $\varepsilon$ 3.73), 333 (3.70), IR (ZnSe) $v_{\max } 3369,2936,1684,1627,1580,1498$, $1457,1377,1284,1252,1210,1142,1052,888 \mathrm{~cm}^{-1}$, High Resolution Electrospray Ionization Fourier Transformation mass spectrometry (HRESIFTMS) (m/z) 385.1648 (calcd for $\mathrm{C}_{22} \mathrm{H}_{24} \mathrm{O}_{6}+\mathrm{H}, 385.1651$ ), for ${ }^{1} \mathrm{H}$ and ${ }^{13} \mathrm{C}$ NMR see Table 1.

Glabramycin B (2): $[\alpha]^{23}{ }_{\mathrm{D}}-0.8\left(c 0.6, \mathrm{CH}_{3} \mathrm{OH}\right), \mathrm{UV}\left(\mathrm{CH}_{3} \mathrm{OH}\right) \lambda_{\max } 269$ (log $\varepsilon$ 3.39), IR (ZnSe) $v_{\max } 3445,2966,2933,1722,1693,1661,1465,1375$, 1239, 1190, 1128, $1013 \mathrm{~cm}^{-1}$, HRESIFTMS $(\mathrm{m} / \mathrm{z}) 387.1802$ (calcd for $\left.\mathrm{C}_{22} \mathrm{H}_{26} \mathrm{O}_{6}+\mathrm{H}, 387.1808\right)$, for ${ }^{1} \mathrm{H}$ and ${ }^{13} \mathrm{C}$ NMR see Table 1.

Glabramycin C (3): $[\alpha]^{23}{ }_{\mathrm{D}}-1.3\left(c 0.6, \mathrm{CH}_{3} \mathrm{OH}\right), \mathrm{UV}\left(\mathrm{CH}_{3} \mathrm{OH}\right) \lambda_{\max } 277$ (log $\varepsilon$ 3.49), IR (ZnSe) $v_{\max } 3445,2965,2933,1735,1657$ 1466, 1386, 1349, $1307,1284,1259,1184,1151,1130,1094,1011 \mathrm{~cm}^{-1}$, HRESIFTMS $(\mathrm{m} / \mathrm{z})$ 385.1647 (calcd for $\mathrm{C}_{22} \mathrm{H}_{22} \mathrm{O}_{6}+\mathrm{H}, 385.1651$ ), for ${ }^{1} \mathrm{H}$ and ${ }^{13} \mathrm{C}$ NMR see Table 1 .

\section{Two-plate differential sensitivity rpsD assay}

Staphyloccus aureus cells (RN450) carrying plasmid S1-782B bearing antisense to $r p s \mathrm{D}$ (AS-RNA strain) or a vector (control strain) were inoculated from a frozen vial source into a tube containing $3 \mathrm{ml}$ of Miller's LB Broth (Invitrogen, Carlsbad, CA, USA) plus $34 \mu \mathrm{g} \mathrm{ml}^{-1}$ of chloramphenicol. Tubes were incubated at $37^{\circ} \mathrm{C}$ at 220 r.p.m. for $18-20 \mathrm{~h}$ and kept at room temperature $\left(23^{\circ} \mathrm{C}\right)$ until use. Miller's LB broth was supplemented with $1.2 \%$ Select agar (Invitrogen), $0.2 \%$ glucose, $15 \mu \mathrm{g} \mathrm{ml}^{-1}$ chloramphenicol and $12 \mathrm{~mm}$ of xylose (only for the antisense strain). The $\mathrm{OD}_{600}$ of the culture was measured and diluted to $1 / 1000$, and an OD 3.0 culture was inoculated. Next, $100 \mathrm{ml}$ of the culture media was poured into each NUNC plate, the well-caster templates were placed into the agar and the agar was allowed to solidify. Thereafter, $20 \mu \mathrm{l}$ of the test samples were added to the wells and the plates were incubated at $37^{\circ} \mathrm{C}$ for $18 \mathrm{~h}$ and zones of inhibition were measured. MDC (minimum detection concentration) values were determined by two-fold serial dilution.

\section{Antibiotic assay (MIC)}

The MIC (minimum inhibitory concentration) against each of the strains was determined as described earlier and under the guidelines of the National Laboratory Standards Institute (NLSI). The Cells were inoculated at $10^{5} \mathrm{cfu} \mathrm{ml}^{-1}$, followed by incubation at $37^{\circ} \mathrm{C}$ with a 2 -fold serial dilution of compounds in the growth medium for $20 \mathrm{~h}$. MIC is defined as the lowest concentration of an antibiotic inhibiting visible growth

\section{Macromolecular synthesis inhibition}

The assay was carried out as described earlier. Briefly, mid-log $\left(A_{600}=0.5-0.6\right)$ $S$. aureus growths were incubated with an increasing concentration of each inhibitor at $37^{\circ} \mathrm{C}$ for $20 \mathrm{~min}$ with $1 \mu \mathrm{Ci} \mathrm{ml}^{-1} 6$ - $\left[{ }^{3} \mathrm{H}\right]$ thymidine, $1 \mu \mathrm{Ci} \mathrm{ml}^{-1} 5,6$ $\left[{ }^{3} \mathrm{H}\right]$ uracil or $5 \mu \mathrm{Ci} \mathrm{ml}^{-1} 4,5-\left[{ }^{3} \mathrm{H}\right]$ leucine, to measure DNA, RNA and protein synthesis, respectively. The reaction was stopped by the addition of $10 \%$ trichloroacetic acid and the cells were harvested using a glass fiber filter 
(Perkin-Elmer Life Sciences, Waltham, MA, USA, 1205-401). The filter was dried and counted with a scintillation fluid.

\section{ACKNOWLEDGEMENTS}

We thank John Ondeyka for some initial help.

1 Poehlsgaard, J. \& Douthwaite, S. The bacterial ribosome as a target for antibiotics. Nat. Rev. Microbiol. 3, 870-881 (2005).

2 Singh, S. B. \& Barrett, J. F. Empirical antibacterial drug discovery-foundation in natural products. Biochem. Pharmacol. 71, 1006-1015 (2006).

3 Ramakrishnan, V. Ribosome structure and the mechanism of translation. Cell 108, 557-572 (2002).

4 Culver, G. M. Assembly of the 30 S ribosomal subunit. Biopolymers 68, 234-249 (2003).

5 Ogle, J. M., Carter, A. P. \& Ramakrishnan, V. Insights into the decoding mechanism from recent ribosome structures. Trends Biochem. Sci. 28, 259-266 (2003).

6 Grundy, F. J. \& Henkin, T. M. The rpsD gene, encoding ribosomal protein S4, is autogenously regulated in Bacillus subtilis. J. Bacteriol. 173, 4595-4602 (1991).

7 Forsyth, R. A. et al. A genome-wide strategy for the identification of essential genes in Staphylococcus aureus. Mol. Microbiol. 43, 1387-1400 (2002).

8 Young, K. et al. Discovery of FabH/FabF inhibitors from natural products. Antimicrob. Agents Chemother. 50, 519-526 (2006).

9 Singh, S. B., Phillips, J. W. \& Wang, J. Highly sensitive target based whole cell antibacterial discovery strategy by antisense RNA silencing. Curr. Opin. Drug Discov. Dev. 10, 160-166 (2007).

10 Wang, J. et al. Platensimycin is a selective FabF inhibitor with potent antibiotic properties. Nature 441, 358-361 (2006).

11 Wang, J. et al. Platencin is a dual fabf and fabh inhibitor with potent in vivo antibiotic properties. Proc. Natl Acad. Sci. USA 104, 7612-7616 (2007).

12 Singh, S. B. et al. Isolation, structure, and absolute stereochemistry of platensimycin, a broad spectrum antibiotic discovered using an antisense differential sensitivity strategy. J. Am. Chem. Soc. 128, 11916-11920, 15547 (2006).

13 Jayasuriya, H. et al. Isolation and structure of platencin: a novel FabH and FabF dual inhibitor with potent broad spectrum antibiotic activity produced by Streptomyces platensis MA7339. Angew. Chem. Int. Ed. Engl. 46, 4684-4688 (2007).
14 Singh, S. B. et al. Discovery of lucensimycins A and B from Streptomyces lucensis MA7349 using an antisense strategy. Org. Lett. 8, 5449-5452 (2006).

15 Singh, S. B., Zink, DL, Herath, KB, Salazar, O \& Genilloud, O Discovery and antibacterial activity of lucensimycin $\mathrm{C}$ from Streptomyces lucensis. Tetrahedron Lett. 49, 2616-2619 (2008).

16 Singh, S. B. et al. Isolation, structure, and antibacterial activities of lucensimycins D-G, discovered from Streptomyces lucensis MA7349 using an antisense strategy (perpendicular). J. Nat. Prod. e-pub ahead of print 30 December 2008 (2008).

17 Ondeyka, J. G., et al. Coniothyrione, a chlorocyclopentandienylbenzopyrone as a bacterial protein synthesis inhibitor discovered by antisense technology. J. Nat. Prod. 70, 668-670 (2007).

18 Zhang, C. et al. Isolation, structure and antibacterial activity of pleosporone from a pleosporalean ascomycete discovered by using antisense strategy. Bioorg. Med. Chem. 17, 2162-2166 (2009).

19 Zhang, C. et al. Isolation, structure and antibacterial activity of phaeosphenone from a phaeosphaeria sp. Discovered by antisense strategy. J. Nat. Prod. 71, 1304-1307 (2008).

20 Zhang, C. et al. Discovery of okilactomycin and congeners from Streptomyces scabrisporus by antisense differential sensitivity assay targeting ribosomal protein S4. J. Antibiot. (Tokyo) 62, 55-61 (2009).

21 Asami, Y. et al. Azaspirene: a novel angiogenesis inhibitor containing a 1-oxa-7azaspiro[4.4]non-2-ene-4,6-dione skeleton produced by the fungus Neosartorya sp. Org. Lett. 4, 2845-2848 (2002).

22 Wong, S. M., et al Fiscalins: new substance $P$ inhibitors produced by the fungus Neosartorya fischeri. Taxonomy, fermentation, structures, and biological properties. J. Antibiot. (Tokyo) 46, 545-553 (1993).

23 Fujimoto, H., Ikeda, M., Yamamoto, K. \& Yamazaki, M. Structure of fischerin, a new toxic metabolite from an ascomycete, Neosartorya fischeri var. fischeri. Nat. Prod. 56, 1268-1275 (1993).

24 Proksa, B., Uhrin, D., Liptaj, T. \& Sturdikova, M. Neosartorin, an ergochrome biosynthesized by Neosartorya fischeri. Phytochemistry 48, 1161-1164 (1998).

25 Hong, S. B., Go, S. J., Shin, H. D., Frisvad, J. C. \& Samson, R. A. Polyphasic taxonomy of Aspergillus fumigatus and related species. Mycologia 97, 1316-1329 (2005).

26 Zhang, C. et al. Isolation, structure, and antibacterial activity of philipimycin, a thiazolyl peptide discovered from Actinoplanes philippinensis MA7347. J. Am. Chem. Soc. 130, 12102-12110 (2008).

27 Kodali, S. et al. Determination of selectivity and efficacy of fatty acid synthesis inhibitors. J. Biol. Chem. 280, 1669-1677 (2005).

28 Onishi, H. R. et al. Antibacterial agents that inhibit lipid A biosynthesis. Science 274, 980-982 (1996). 